\title{
Biomass Briqmure: BBQ Briquettes Fuel Source from Cow Manure
}

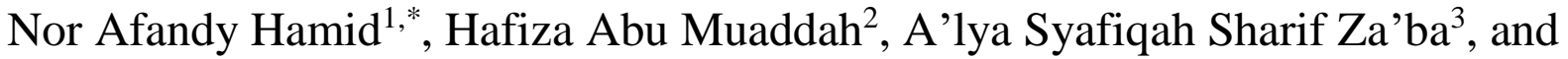 \\ Muhammad Danial Nor Afandy ${ }^{3}$
}

\author{
${ }^{1}$ Universiti Malaysia Terengganu (UMT), Terengganu, Malaysia \\ ${ }^{2}$ Maktab Rendah Sains MARA (MRSM) Sungai Besar, Sabak Bernam, Selangor, Malaysia \\ ${ }^{3}$ Maktab Rendah Sains MARA (MRSM) Kota Putera, Besut, Terengganu, Malaysia \\ *Corresponding author email: norafandy@umt.edu.my
}

\begin{abstract}
Cow manure is an excreta of livestock animal waste, is a cheap and easily available bioresource on our planet. Cow manure or commonly termed as cow dung, has given a decent amount of attention in the recent times due to the various applications that may be utilised for the society. Traditionally, cow manure has been used as a fertilizer, soil amendment, energy source, and even as a construction material. Livestock manure contains many useful and important, recyclable materials, including nutrients, organic matter, solid wastes, energy, and fibre. The main objective of the study is to increase the potential and beneficial uses of livestock wastes of cow manure as a cheaper and eco-friendly BBQ briquettes (Briqmure) as an alternative household fuel energy. Briqmure were produced from cow manure that was considered as a livestock and agricultural wastes. The method and process of Briqmure manufacturing were done according to the standard and improvised procedures. Cow manure was collected, mixed with water and finally treated with heat. The cow manure mixture was put into the briquette molds to dry. The results show that Briqmure made from cow manure has good combustion capacity. The cost analysis carried out shows the economic viability of using the Briqmure as an outstanding, low cost and eco-friendly substitute of the current practices using conventional cooking fuels available. Therefore, the utilisation of cow manure for Briqmure production will reduce environmental degradation and pollution by minimising cow manure waste in the livestock and agricultural industry.
\end{abstract}

Keywords: Cow Manure, Briquettes, Biomass, Fuel, Environment

\section{INTRODUCTION}

Environmental sustainability is a major global issue nowadays, hence is one of the biggest challenges and most important targets of the present times. Most of the main factor of the environmental destruction are due to human population and their activities such as urbanization, industrialization and modern agricultural practices [1]. The heavy usage of major energy sources such as fossil fuels has cause the release of tremendous amount of greenhouse gaseous into the atmosphere [2]. Alternatives renewable energy and fuels such as biomass from agricultural and livestock wastes are making breakthrough to energy sector for production of green energy [3].

The livestock sector contributes significantly to generating employment in rural region of Malaysia, especially for marginal farmers, and most important providing nutririous food to millions of people. According to livestock census report, national livestock population stands at 3.3 million, compromising mainly of cows, buffaloes, sheep, goats and pigs [4]. Consistent increase in livestock numbers over the 
years has led to generation of enormous amount of livestock waste. Subsequently, the livestock waste will significantly affect water and soil pollution, and ground water contamination respectively [5]. The livestock waste is a major source of noxious gaseous, harmful pathogens and odor; hence, it is a public health and environment concern [6]. Scientific measure to stop, reduce or recycle the livestock waste are greatly required.

Livestock and poultry manure are composed of animal faeces and urine and may contain livestock bedding, additional water and wasted feed [7]. Henceforth, manure is both a natural by-product of livestock production and an excellent source of plant nutrients. Manure have been commonly used as a fertilizer, soil amendment, energy source, and even as a construction material. Livestock manure contains many useful and important, recyclable materials, including nutrients, organic matter, solid wastes, energy, and fibre [8]. In some countries, such as India, cow manure and cow's urine can be used as fertilizers and pest repellent respectively [9]. The use of manure as a fertilizer for crop production is very beneficial way to recycle manure nutrients within an agricultural system. Agricultural and livestock wastes remain the most promising resource to resolve the challenges of emissions, deforestation and climate crisis which has been largely contributed by the adverse environmental activities by the people of the planet [10].

Cow manure mainly consists of lignin, cellulose and hemicellulose [11]. Cow manure is an organic waste containing major sources of noxious gases, pathogens and odour, and harmful to the environment and public health. Therefore, livestock waste and manure should be managed properly to mitigate production of these pollutants and to conserve our environment. Proper utilization of livestock manure into biogas, compost and vermicompost can be very useful to increase crop yield, sustainability and environmental protection [6]. Cow manure is also one of the biomasses that can be used as an alternative energy and products [12]. Nowadays, the environmental considerations are critically very important, it is not only just saving the environment for pollution, but also a scope of resource efficiency of fully utilise the livestock wastes. Processing cow manure into paper pulp is alternative way to recycle the livestock waste and to reduce our sole dependency on trees' pulps.

A pile of cow manure is not exactly the most beautiful thing to look at, nor does it smell very good. Despite its unappealing aroma and appearance, cow manure can be actually very beneficial. It fertilizes, it's organic, it retains moisture, and it can be used for many useful resources such as paper pulps. Cow manure has a lot of uses despite its dirty appearance and bad smell. By processing the cow manure into paper pulps, we're definitely able to reduce the deforestation and destruction of mangrove floras.

The objectives of the research are. to produce the ecofriendly biomass barbecue briquettes from the livestock waste, particularly from cow manure, and to highlight the importance of utilization of agricultural wastes in order to reduce environmental pollution.

Our hypothesis is that cow manure has great potential and highly useful to be utilized as eco-friendly beneficial products such BBQ briquettes for public consumers.

\section{MATERIALS AND METHODS}

\subsection{Materials}

The material and equipment used in the production of the paper pulp are cow manure, water and mould. The cow manure was collected from a local farmer. The water used was gotten from the running tap water in the science laboratory of MRSM Kota Putra. The mould used was fabricated locally based on the required size and shape.

\subsection{Methods}

First step, the dried cow manure was put into the beaker. The manure was mixed with water to form the suitable mixture. The manure was treated with a sodium hydroxide solution which partially removes the lignin and other impurities, including dead cells from the cellulose of the manure. The next process was to bleach the separated cellulose with sodium hypoclorite. The manure mixture was put onto the linen cloth for filtration. The filtration process was assisted by washing the mixture with running water, till there was no smell left and all the extras in the manure mixture were washed off.

The next process was to grind the cellulose fibres with a blender mixture to obtain the finest texture. The cellulose fibres were then put into the tray and press it down with a compactor. Finally left it to dry as the final product.

\subsection{Product Testing and Analysis}

For the competency usage of biomass briqmure briquette as barbecue fuel, it should meet certain desirable property values. The cellulose pulp of the briqmure product was tested and examined for its physical and chemical tests, such as strengthness, water adsorption rate, combustibility and heat release.

Tensility and strengthness is the maximum weight load a briquette can withstand before cracking or breaking. 


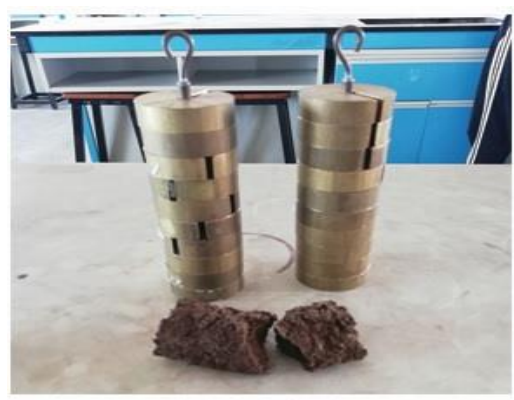

Figure 1 Testing the strengthness of Briqmure

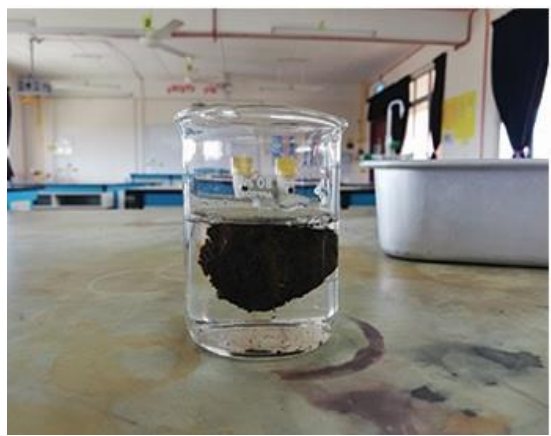

Figure 2 Testing the water adsorption rate of Briqmure

The briquette is immersed in water maintained at the atmospheric temperature for 10 minutes to determine the water adsorption rate. The initial weight of the briquette before the immersion, and the final weight of the briquette after the immersion were taken for comparison values.

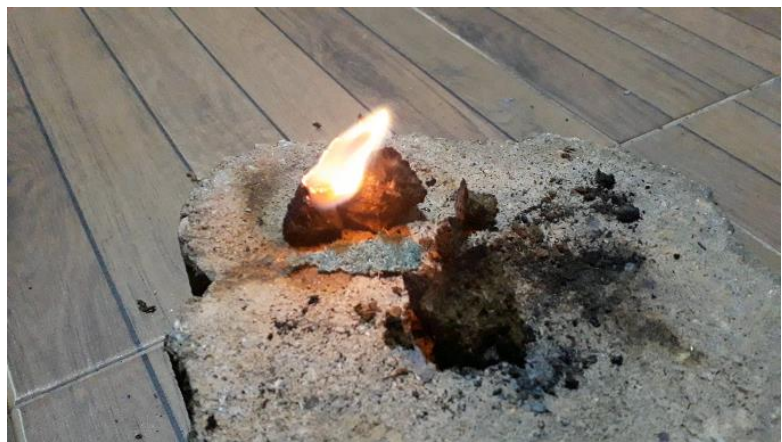

Figure 3 Testing the combustibility of Briqmure

Briquette burning rate was determined according to method used by Davies and Davies [13]. Briquette sample of known weight was placed on a concrete block and put on a flame. The duration of briquette flame was recorded.

\section{RESULTS}

Biomass barbecue briquettes from cow manure (Briqmure) was successfully manufactured and display an excellent and a very promising product. The physical characteristics of the Briqmure are considerately tensile, strong and sturdy. Its chemical characteristics shows that the Briqmure has a low moisture content. Hence, it gives a good and promising potential to be used as an alternative for barbecue briquettes.

Table 1 Testing the strengthness of Briqmure

\begin{tabular}{lc}
\hline \multicolumn{1}{c}{ Tensile and Strength Test } & Results \\
\hline Weight of briquette $(\mathrm{g})$ & 19.25 \\
Surface area of briquette $\left(\mathrm{cm}^{2}\right)$ & 160.2 \\
Weight of load $(\mathrm{g})$ & 2000 \\
\hline
\end{tabular}

Table 2 The test results of the water adsorption rate of Briqmure

\begin{tabular}{lc}
\hline \multicolumn{1}{c}{ Water Absorption } & Results \\
\hline Volume of water $(\mathrm{ml})$ & 50 \\
Time period (min) & 10 \\
Initial weight of briquette $(\mathrm{g})$ & 6.1 \\
Final weight of briquette $(\mathrm{g})$ & 13.7 \\
\hline
\end{tabular}

Table 3 The test results of the combustibility of Briqmure

\begin{tabular}{lc}
\hline \multicolumn{1}{c}{ Combustibility } & Results \\
\hline Weight of briquette $(\mathrm{g})$ & 7.5 \\
Time of combustibility (min) & 30 \\
\hline
\end{tabular}

Table 4 The test results of the heat release of Briqmure

\begin{tabular}{cc}
\hline Heat Release & Results \\
\hline Heat release by briquette $(\mathrm{J} / \mathrm{g})$ & 323.58 \\
\hline
\end{tabular}

The results show that Briqmure made from cow manure has excellent combustion capability. The cost analysis carried out shows the economic feasibility of using BBQ Briqmure as an outstanding, low cost and eco-friendly substitute for conventional cooking fuels.

The physical characteristics of the Briqmure briquettes are considerately tensile, strong and sturdy. Its chemical characteristics shows that the paper pulp has a low moisture content and produce sufficient energy to heat the barbeque grill. Thus, it has proved our hypothesis that car manure will gives a good and promising potential to be used as an alternative for BBQ briquettes.

\section{CONCLUSION}

Cow manure has been used traditionally as a rich soil fertilizer and some other useful products. However, most of the livestock wastes such as cow manure has been 
ignored and washed away towards environment. Thus, some beneficial method to make fully use of livestock wastes should be implemented and supported.

Cow manure has a great potential as a renewable energy source that can be used as a biogas for generating heat. One of the promising perspectives is to manufacture the biomass barbecue briquettes from cow manure, known as Briqmure. The successful attempt to produce Briqmure will led to better environment care for the future generation. Briqmure is ultimately gives a major impact towards our environment and society. Briqmure production will effectively reduce environmental pollution by minimizing cow manure wastes in the livestock industry. The effective use of Briqmure as paper pulp would contribute to reduce environmental degradation, deforestation, destruction of the mangrove swamps and trees. The main reason of the research is to save our sustainability and utilise our natural resources and appreciate the values of agricultural wastes and preventing their adverse impact towards our environment. Furthermore, it is a part of our Educational for Sustainable Development (ESD) for younger and future generation to appreciate the values of agricultural wastes and prepare them for the development of prosperous Madani Nation.

Future work will be required to analyse the standard texture and strength of the Briqmure. The potential usage of the Briqmure as an insect or mosquito repellent, mosquito repellent of vape mat, fragrant incense for fumigation, MDF (medium density fibres) for furniture will be studied further. There are a lot potential need to be explored with the enormous quantity of agricultural wastes.

\section{ACKNOWLEDGMENT}

Authors thanks to KEMENRISTEKDIKTI-BRIN for the financial support to through Project No. 182/SP2H/LT/DRPM/2020 (Penelitian Dosen Pemula).

\section{REFERENCES}

[1] N. K. Arora, Environmental Sustainability Necessary for Survival. Environmental Sustainability, 1 (2018), 1-2.

[2] U. B. Deshannavar, P. G. Hegde, Z. Dhalayat, V. Patil, S. Gavas, Production and Characterization of Agro-based Briquettes and Estimation of Calorific Value by Regression Analaysia: An Energy Application. Materials Science for Energy Technologies, 1 (2018), 125-181.

[3] J. Kers, P. Kulu, A. Arunjiit, V. Laurmaa, P. Krizan, L. Soos, U. Kask, Determination of Physical, Mechanical and Burning Characteristics of Polymeric Waste Material Briquettes. Etonian Journal of Engineering, 16 (4) (2010), 307-316.
[4] JPV, Jabatan Perkhidmatan Veterinar. Kementerian Pertanian dan Industri Asas Tani, Malaysia, 2019.

[5] G. Kaur, Y. S. Brar, D. P. Kothari, Potential of Livestock Generated Biomass: Untapped Energy Source in India. Energies, (2017). doi: 10.3390/en10070847

[6] C. D. Miranda, P. R. Wankhade, V. Purwar, S. Bindu, A Multipurpose Approach in Utilizing the Cow Dung. Chapter 4 in Book: Recent Research Trends in Veterinary Sciences and animal Husbandry (Volume 6), Publisher AkiNik Publications, Delhi, 2019, 41 - 55.

[7] Manitoba, Properties of Manure, 2015. https://www.gov.mb.ca/agriculture/environment/nutrien t-management/pubs/properties-of-manure.pdf.

[8] U. S. Environmental Protection Agency (EPA), Beneficial Uses of Manure and Environmental Protection, 2015. https://www.epa.gov/npdes/beneficial-uses-manureand-environmental-protection.

[9] A. Raj, M. K. Jhariya, P. Toppo, Cow Dung for Ecofriendly and Sustainable Productive Farming. International Journal of Scientific Research, 3 (10) (2014), 201-202.

[10] R. Shuma, D. M. Madyira, Production of loose biomass briquettes from agricultural and forestry residues. Procedia Manufacturing, 7 (2017), 98-105.

[11] K. K. Gupta, K. R. Aneja, D. Rana, Current Status of Cow Dung as a Bioresource for Sustainable Development. Bioresources and Bioprocessing, 3 (2016), 28-39.

[12] A. Anatasya, N. A. K. Umiati, A. Subagio, The Effect of Binding Types on the Biomass Briquette Calorific Value from Cow Manure as a solid Energy Source. E3S Web of Conferences, 125 (2019), 1-5.

[13] R. M. Davies, O. A. Davies, Physical and Combustion Characteristics of Briquettes Made from Water Hyacinth and Phytoplankton Scum as Binder. Journal of Combustion, (2013). doi: $10.1155 / 2013 / 549894$ 